\title{
Types of Bilingual Presentation in the English-Latin Terence ${ }^{1}$
}

\author{
Demmy Verbeke
}

The history of bilingualism in the Early Modern Period is written by studying the sources which inform us about the spoken or written exchanges between individuals or groups of people. Since we obviously do not have sound recordings of these exchanges, we have to rely exclusively on texts: this is the handwritten or printed forms of communication. Naturally, we need to take a critical approach towards these sources and need to make sure we understand, to the best of our abilities, how and why these texts were produced and how they were put to use. This essay therefore takes what one might call a book history approach when studying the interaction between Latin and the vernacular. It focuses on books in which the Classical language appears together with the vernacular, not only in the same book, but even on the same page; and aims to present the different formats of bilingual presentation at the disposal of the author or editor who wishes to present a text in two languages.

The corpus of bilingual editions under scrutiny in this essay consists of English translations of Terence printed between 1473 and 1640. This is the period covered by the most important bibliographical tools in the field, namely the ShortTitle Catalogue of Books Printed in England, Scotland, \& Ireland and of English Books Printed Abroad and the Renaissance Cultural Crossroads catalogue. ${ }^{2}$ A considerable number of English versions of Terence were printed during this period. These were intended mainly, but not exclusively, for didactic use and thus provide us with an insight in the ways and means by which students

1 This contribution was prepared in the context of the project Renaissance Cultural Crossroads: An Analytical and Annotated Catalogue of Translations, 1473-1640, funded by the Leverhulme Foundation for 2007-2010 and executed at the Centre for the Study of the Renaissance in the University of Warwick. I wish to thank Brenda Hosington and Ian Fielding for their comments on this essay.

2 Pollard and Redgrave, A Short-Title Catalogue of Books Printed in England, Scotland, \& Ireland and of English Books Printed Abroad $1475^{-1640}$ (further: STC), now incorporated in the online English Short Title Catalogue (http://estc.bl.uk). The Renaissance Cultural Crossroads catalogue is available online since 2010 (http://www.hrionline.ac.uk/rcc/). 
were educated to achieve linguistic competence in Latin. It is well attested in studies of the English school system, and especially in T.W. Baldwin's William Shakspere's Small Latine \& Lesse Greeke, that no schoolboy attending grammar school could ever escape Terence. Terence was promoted-for instance in the highly influential De ratione studii of Erasmus - as the ultimate model of colloquial Latin, as the model stylist and as a moralist who showcases men's vices. ${ }^{3}$ In England, Terence was taught especially in the lower forms, typically through study of the comedies themselves, as well as memorization of phrasebooks based on Terence. The corpus of English translations of Terence thus includes translations of specific plays and translations of the complete works, as well as anthologies which collect quotations from Terence and commonplace phrases couched in Terentian idiom. A tally of all these translations of Terence printed before 1640 and listed in the appendix at the end of this essay provides us with eight separate books and twenty-five editions including the reprints. A vast majority of these are bilingual publications. Only the Andria (1588) by Maurice Kyffin and the Andria and the Eunuch (1627) by Thomas Newman do not print the source text, and even then, Latin is not completely absent: Kyffin's translation comes with Latin preliminaries and Newman's with a Latin motto on the title page.

The first printed English-Latin version of Terence is the phrasebook Vulgaria quedam abs Terencio in Anglicam linguam traducta, published in 1483 in Oxford and reprinted six times up to 1529. It was published in the same year, by the same printer, as the Compendium totius grammaticae of John Anwykyll, the schoolmaster of Magdalen College School in Oxford, who is credited for being 'the first English grammarian to have his work printed and to publish school textbooks teaching Latin on humanist lines'. ${ }^{4}$ It has therefore been assumed that these Vulgaria were prepared by Anwykyll as well, or were at least intended to be used together with his grammar in the classroom.

A short preliminary poem, in Latin, precedes the actual phrasebook and informs us that this publication is intended for the student who wants to improve his Latin as well as his English: 'Studious boy, you who want to speak

3 'Rursum inter latinos quis vtilior loquendi auctor quam Terentius? Purus, tersus et quotidiano sermoni proximus, tum ipso quoque argumenti genere adolescentiae' (ed. Jean-Claude Margolin in ASD, I-2, pp. 115-16). See also the dedicatory epistle to Erasmus' edition of Terence (i.e. Ep. 2584, 1. 70 ff.) and the recent contribution by Bloemendal, 'Erasmus and Comedy between the Middle Ages and the Early Modern Period'.

4 Orme, 'Anwykyll, John (d. 1487)'. 
English and Latin words, focus your mind on this little book. ${ }^{5}$ The presentation is interlinear. In the first couple of editions, each English phrase is followed by the Latin equivalent. The fact that the English comes first indicates that this was the entry language; but the Latin derives prominence from being printed in a larger font. It is interesting to note, however, that this layout changes in the editions of 1510 and 1529 , where the interlinear presentation is preserved, but the English and the Latin trade places: the Latin now comes first, while the English is printed in a larger font. The switch suggests that the intended use of these reprints may be different from the original one. The English-Latin version was probably intended mainly to teach the students how to speak and write better Latin, starting from the English expressions and translating them into Latin. The Latin-English versions, on the other hand, start from the Latin and thus seem to be primarily designed to help students to translate Latin into English.

Another bilingual phrasebook, entitled Floures for Latine spekynge selected and gathered oute of Terence, was first published in 1533/4 and went through seven editions before 1581 . This new anthology was compiled by the playwright and schoolmaster Nicholas Udall. ${ }^{6}$ Just as the previous phrasebook, it was intended to serve a double purpose: Udall says explicitly in his dedicatory epistle that he not only wants to teach students to translate English phrases into correct Latin, but also wants to instruct them in how to translate Latin into appropriate English:

Porro latina ipse anglice interpretatus sum, quo vos quoque latina vernacule, aut e contrario latine vernacula absque molestia vel negotio, et cum aliqua ratione ac gratia, nec interim ineptis prorsus atque absurdis, quod plerique faciunt, sed appositis et accomodatis verbis reddere addiscatis.

Moreover, I myself have translated the Latin into English. This way, you can learn to translate Latin into the vernacular, and the other way around, vernacular into Latin. And you can do this without hassle or trouble, and with a certain reason and grace, not — as many do-by using completely senseless and absurd words, but with appropriate and suitable vocabulary. ${ }^{7}$

5 Vulgaria quedam abs Terencio in Anglicam linguam traducta, fol. $\mathrm{n} 1 \mathrm{r}$ : 'Hunc studiose puer menti committe libellum / Anglica qui cupis et verba latina loqui'.

6 Steggle, 'Udall, Nicholas (1504-1556)'.

7 Floures for Latine spekynge selected and gathered oute of Terence, fol. $3 \mathrm{v}$. 
Despite the fact that they are both bilingual phrasebooks based on Terence and primarily used in schools, there are a number of differences between the fifteenth-century Vulgaria and the sixteenth-century Floures. The Latin comes first in the Floures, but the English follows on the same line and is printed in the same font size. Moreover, Udall does not limit himself to a mere list of Latin and English expressions, but adds, where appropriate and needed, all sorts of commentary in Latin, with the occasional translation of a sentence into English. As a result, the dominant language in these Floures is Latin, although the English title page might suggest otherwise. Another difference is the intended use, which can be surmised from the organisation of the books. The Vulgaria were a fairly limited collection of phrases which the students were most probably expected to learn by heart. The first couple of editions of the Floures, on the other hand, contain an index (omitted from the revised editions printed in 1575 and 1581), which seems to suggest that the book was not only a schoolbook, but could also be used as a work of reference, for instance by Renaissance dramatists or compilers of dictionaries. ${ }^{8}$

We now turn our attention to the translations in the more traditional sense of the word. The first one of these, Terens in Englysh, was probably printed in Paris around 1520 and remained anonymous. The book only contains the Andria, which is preceded by a long poem by the translator, who also adds some verses at the end of the book. In these paratexts, the translator discusses the act of translating and the status of the English language. He argues that, thanks to the efforts of the so-called masters of English poetry, namely John Gower, Geoffrey Chaucer, and John Lydgate, the English language is 'amplyfyed so / That we therin now translate as well may / As in eny other tongis other can do.9 Thus, the status of English has changed so much that it can be seen to rival the other vernaculars. Moreover, the translator observes that, while the English language cannot provide an equivalent for every word in the Classical languages, the same is also true the other way around: 'yet the greke tong $r$ laten dyuers men say / Haue many wordys can not be englyshid this day / So lyke wyse in englysh many wordys do habound / That no greke nor laten for them can be found. 10

The vernacular occupies a central place in this book: the title is only stated in English, the verses added before and after the comedy are in English, and Latin

8 Starnes, 'Literary Features of Renaissance Dictionaries', pp. 45 and 48; and idem, Renaissance Dictionaries English-Latin and Latin-English, pp. 81 and 233.

9 Terens in englysh, fol. Aiv. This translation is edited by Meg Twycross in her Terence in English. 
is literally marginalized in the mise-en-page. ${ }^{11}$ This dominance of English is explained by the intended use of the book and by its audience. In contrast with the previous examples and some of the other translations of Terence which we will discuss, this Terens in Englysh is not meant to be a course text. Rather, the prologue and epilogue indicate that the text was meant to be performed.

The next bilingual edition, also entitled Terence in English, was printed in Cambridge in 1598, and contains all six comedies. The translator was the Anglican clergyman Richard Bernard, who translated Terence in the beginning of his career and seems to have focused exclusively on his pastoral work and his religious writings afterwards. ${ }^{12}$ In his dedicatory epistle and his preface to the reader, Bernard stresses the importance of Terence for learning correct, clear and elegant Latin, but especially highlights the moral content of his work: 'in telling the truth by these figments, men might become wise to auoid such vices, and learne to practise vertue; which was Terence purpose in setting these comedies forth in latin, mine in translating them into english.'.13

The text itself is organized to accommodate these different uses of Terence. The Latin text is printed first with marginal notes in Latin. This user-friendly edition of the original is regularly followed by another section in Latin, entitled moralis expositio, which constitutes a concise expression of the moral lesson contained in the relevant scene of the comedy. This is followed by a translation of Terence's text into English, which can be read separately or in combination with the source text, and two sections aimed at language instruction: the formulae loquendi which offer Latin expressions together with their English equivalents, and the sententiae, which are untranslated commonplace Latin sayings. This version of the English-Latin Terence, in other words, combines the elements of the phrasebooks with an annotated edition of the Latin text and a translation into English; and adds the extra element of the moral instruction drawn from Terence. The mise-en-page seems to indicate that the publication could be used as a textbook for schools, but also as reading material for lay people who could apply it for self-tuition and moral instruction.

11 This type of presentation was previously used for annotated texts, with the text in the centre of the page and the glosses in the margin, and was later copied by the translators of the same texts. Cf. Molins, 'Mises en page: Les efforts conjugués des traducteurs et des imprimeurs', pp. 1-2. Molins (pp. 3-4) also lists examples of French translations of Virgil in which the Latin text is similarly marginalized with the translation at the centre of the page.

12 Greaves, 'Bernard, Richard (bap. 1568, d. 1641)'.

13 Terence in English, fol. $2 \mathrm{v}$. 
The two final examples have a more limited scope and are aimed at people who want to use the comedies of Terence to teach or learn Latin. They are the editions by Joseph Webbe, a remarkable figure in English education and book publishing. After having studied medicine in Italy for several years, Webbe returned to England around 1616. He failed to obtain a licence to practice medicine and made a living teaching languages. He developed a 'direct' method to teach Latin, based on imitating phrases from Classical authors rather than learning grammatical paradigms, and designed textbooks to teach according to this system. Webbe was also an entrepreneur and successfully lobbied to obtain copyright for his teaching method and textbook design. ${ }^{14}$ It was Webbe's intention to publish all of Terence's comedies in his new format, but he only managed to finish the Andria and the Eunuch before he died around 1630.

The aim of Webbe's design is to enable students to see immediately the links between Latin sentences and their English equivalents without having to refer to any grammatical explanation. His method is 'clausulary', that is, the Latin text is divided into both simple and compound clauses, which are then numbered. An example is shown in the illustration, where the clause number is found in the middle column. '1.5.4. 51', for instance, means the first comedy of Terence (that is, the Andria), act 5 , scene 4, clause 51. The challenge was to develop a typographical system to print the Latin text, the clause number and the English translation, so that it would be clear which part in one language corresponded to which part in the other language without altering the correct word order of either of the two languages. Webbe's solution is to use three major columns: one column is for the English translation, the middle column for the reference number of the clause, and the third column for the Latin text. The word order of both languages is preserved when one reads the two text columns downwards and from left to right (see for example clause 1.5.4. 56: the English reads 'it is a thing that may presently be knowne', while the Latin reads 'iam sciri potest'). But Webbe also parses the text, using subdivisions with horizontal and vertical lines, so that at a glance, one sees which part of the English sentence in the left-hand column corresponds with which part of the Latin sentence in the right-hand column (see for instance 1.5.4. 56 again, where the vertical line separates 'presently' and 'iam', indicating that these are the words which correspond with each other). Moreover, words which are necessary in English, but are not expressed in the Latin, are added within square brackets (for example, see 1.5.4. 51: '[for them]' is printed in square brackets because there is no corresponding word or set of words in the Latin).

14 Cf. Watson, 'Dr. Joseph Webbe and Language Teaching', and the various contributions by Vivian Salmon listed in the bibliography. 


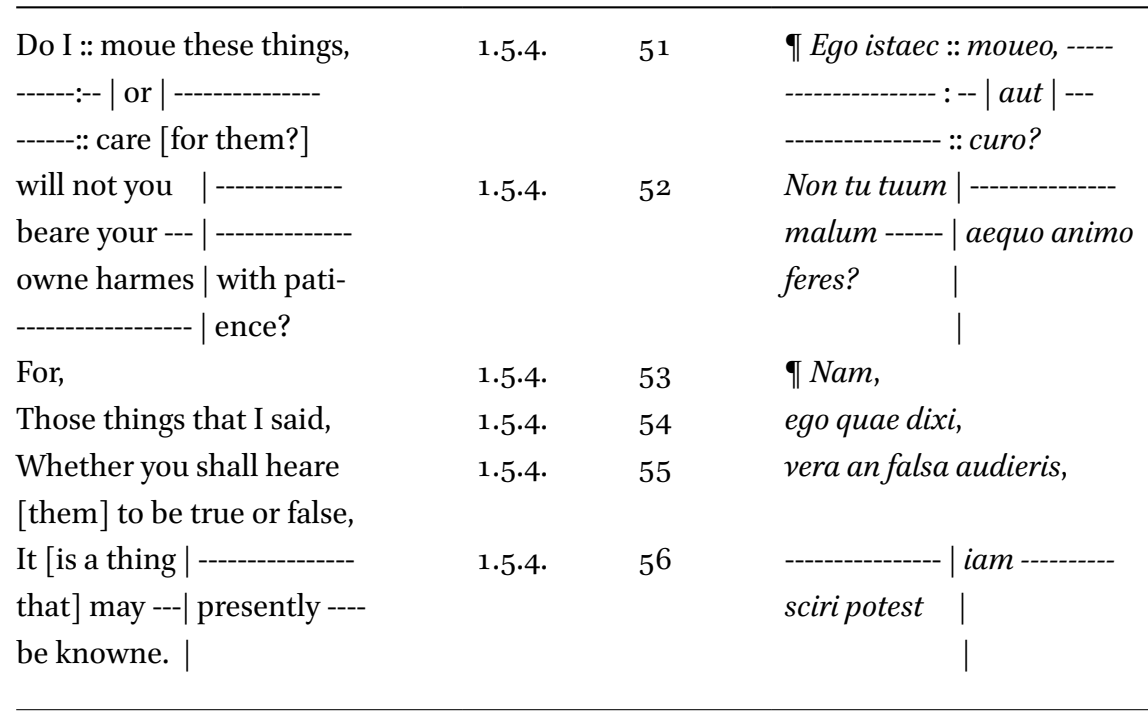

ILLUSTRATION

Example of Webbe's textbook design; excerpt (p. 181) from The first comedy of Pub. Terentius, called Andria.

It is hard to comment on the feasibility of Webbe's method without having used it in a classroom setup for a period of time. In his preface to the Andria, however, Webbe himself admits that not everything went according to plan: 'The Scholes formerly employed to this purpose, haue, by mingling of Methods, been much confused, And the Masters of these Scholes were by pouertie (as they tell) enforced to this mingling. ${ }^{\prime 15}$ As far as we can tell, the method died together with its inventor. Despite the apparent failure of Webbe's method, though, his editions offer yet another form of bilingual presentation. Moreover, they show that there is almost no limit to what is possible just as long as an author is eccentric enough to come up with a new idea and manages to scrape enough money together to put it into print.

This overview of types of bilingual presentation in the English-Latin editions of Terence printed between 1473 and 1640 confirms and expands on the findings of Nikolaus Henkel about bilingual school texts printed before $1500 .{ }^{16}$ Henkel distinguished six types of bilingual presentation in incunabula:

\footnotetext{
15 The first comedy of Pub. Terentius, called Andria, fol. $4 \mathrm{r}$.

16 Henkel, 'Printed School Texts: Types of Bilingual Presentation in Incunabula'. Henkel also discussed several types of mise-en-page of a source text together with its translation in his Deutsche Übersetzungen lateinischer Schultexte, pp. 103-47.
} 
(1) source text printed together with an interlinear translation, (2) books in which text sections in the vernacular are interrupted by text sections in Latin, whereby the Latin language is employed for specific tasks only, (3) source text and translation printed in two columns, (4) Latin text, followed by translation in the vernacular, followed by commentary in the vernacular, (5) summary in the vernacular, followed by Latin text, followed by Latin commentary, and, finally, (6) a particular and rare case in which a printed Latin text with commentary is bound with blank pages in between, used for a handwritten vernacular version.

The first type is also present in the studied corpus of English-Latin editions of Terence, but it is a different kind of interlinear translation. Henkel presented a 1481 edition of Donatus's Ars minor, in which the Latin original is printed together with a German interlinear translation. This German version offered a word-by-word correspondence by providing a literal translation of the Latin word printed directly below it. The vernacular version was thus incomprehensible when read sentence by sentence, since it retained the Latin order of words, and was supposed to be used vertically instead of horizontally. The approach in the Terentian phrasebook from 1483 , however, is different: a perfectly normal English phrase is followed by its Latin equivalent, not in wordfor-word correspondence, but according to the general sense.

The presentation method found in the Floures for Latine spekynge, namely Latin text, followed by a translation, followed by a commentary in Latin, resembles Henkel's fourth and fifth type where text sections in Latin alternate with sections in the vernacular. The Parisian Terens in englysh, on the other hand, reflects the printing of source text and translation in parallel columns (this is Henkel's third type): although the text is not really organized in two columns, it creates a similar effect by placing the English translation in the centre of the page, and adding the Latin source text in the margin.

This overview also adds two new types to the ones distinguished by Henkel: the patented method of parsing the Latin and English text developed by Joseph Webbe and the organization of Richard Bernard's Terence in English, into annotated Latin text, Latin morales expositiones, English translation, bilingual formulae loquendi, and Latin sententiae. Between Henkel and this essay, at least eight types of bilingual presentation in early printed books have thus been identified. It is to be expected that further research will reveal even more possibilities because an author or editor who wanted to publish a text in two languages was, after all, only limited by his own innovative prowess and, of course, by the printers' willingness, competence, and materials.

The survey of English-Latin editions of Terence showcases the different uses that were made of the Classics. It furthermore brings to light how the 
mise-en-page could be arranged to achieve these various goals. Not every bilingual publication served the same purpose and the specific aim of a publication led to a certain type of bilingual presentation, just as a specific bilingual layout steered the reading process. A detailed analysis of bilingual publications using a book history approach can bring us closer to a fuller understanding of the purpose of bilingual editions and the reading processes involved, and can thus reveal at least part of the history of bilingualism in the Early Modern Period.

\section{Appendix: English Translations of Terence Printed between 1473 and $1640^{17}$}

Vulgaria quedam abs Terencio in Anglicam linguam traducta ([Oxford: Theodoric Rood and Thomas Hunt, 1483] = STC 23904) — translator unknown (John Anwykyll?).

Reprinted in London (c.1483, c.1485, c.1505; i.e. STC 23905, STC 23906, STC 23907.3) and Antwerp (1486 = STC 23907).

Revised reprint in London (c.1510, 1529; i.e. STC 23907.7, STC 23908).

Floures for Latine spekynge selected and gathered oute of Terence, and the same translated in to Englysshe, together with the exposition and settynge forthe as welle of suche latyne wordes, as were thought nedefull to be annoted, as also of dyuers grammatical rules, very profytable [and] necessarye for the expedite knowlege in the latine tongue: compiled by Nicolas Vdall (London: Thomas Berthelet, 1533 [i.e. 1534] = STC 23899). Reprinted in London $(1538,1544,1560,1568,1572$; i.e. STC 23900, STC 23900.5, STC 23901, STC 23901.3, STC 23901.7).

Revised and expanded edition with an additional collection by John Higgins printed in London (1575, 1581; i.e. STC 23902, STC 23903).

Terens in englysh ([Paris, P. le Noir?, ca. 1520] = STC 23894) — in fact only a translation of Andria; translator unknown (J. Rastell?).

Andria the first comoedie of Terence, in English. A furtherance for the attainment vnto the right knowledge, \& true proprietie, of the Latin tong. And also a commodious meane of

17 This survey was compiled on the basis of the Renaissance Cultural Crossroads catalogue and checked against Palmer, List of English Editions and Translations of Greek and Latin Classics Printed before 1641, the trial list of translations into English printed between 1475 and 1560 in Bennett, English Books and Readers 1475-1557, pp. 277-319, the list of translations of the Greek and Roman Classical authors before 1600 in Bolgar, The Classical Heritage and its Beneficiaries, pp. 506-541, and the corrections published in Nørgaard, 'Translations of the Classics into English before 160o' and Cummings and Gillespie, 'Translations from Greek and Latin Classics 1550-1700: A Revised Bibliography'. See also Lathrop, Translations from the Classics into English from Caxton to Chapman, 1477-1620. 
help, to such as haue forgotten Latin, for their speedy recouering of habilitie, to vnderstand, write, and speake the same. Carefully translated out of Latin, by Maurice Kyffin (London: T[homas] E[ast] for Thomas Woodcocke, 1588 = STC 23895).

Terence in English. Fabulae comici facetissimi et elegantissimi poetae Terentii omnes Anglicae factae primumque hac noua forma nunc editae: opera ac industria R.B. in Axholmiensi insula Lincolnsherij Epvvortheatis (Cambridge: John Legat, 1598 = STC 23890) — trad. Richard Bernard.

Reprinted in London (1607, 1614, 1629; i.e. STC 23891, STC 23892, STC 23893).

The two first comedies of Terence called Andria, and the Eunuch newly Englished by Thomas Newman. Fitted for schollers priuate action in their schooles (London: G. M[iller], 1627 = sTC 23897).

The first comedy of Pub. Terentius, called Andria, or, The woman of Andros, English and Latine: claused for such as would write or speake the pure language of this author, after any method whatsoeuer, but especially after the method of Dr. Webbe (London: Felix Kyngston for Philip Waterhouse, 1629 = STC 23896) — trad. Joseph Webbe.

The second comedie of Pub. Terentius, called Eunuchus, or, The eunuche, English and Latine: claused for such as would write or speake the pure language of this author, after any method whatsoeuer, but especially after the method of Dr. Webbe. The vses whereof the reader may finde in the epistle before the first comedie (London: Adam Islip, 1629 = STC 23898) - trad. Joseph Webbe.

Reprinted in London (1629 = STC 23898a). 